\title{
The Impact of Bridges on the Process of Water Turbidity on the Example of Large Lowland Rivers
}

\author{
Dawid Szatten ${ }^{1 *}$, Michał Habel', Zygmunt Babiński', Oleksandr Obodovskyi' \\ 1 Department of Revitalization of Waterways, Institute of Geography, Kazimierz Wielki University in Bydgoszcz, \\ Koscieleckich Square 8, 85-033 Bydgoszcz, Poland \\ * Corresponding author's e-mail: szatten@ukw.edu.pl
}

\begin{abstract}
The transformations of river channels as a result of human activity may reflect the level of anthropogenic pressure. Recorded in macroscale, they are indicators of transformations for the larger part of the river basin, while in the microscale they usually refer to its fragment. The human activity that has the strongest influence on the fluvial processes, including suspended sediment transport, is the interference in the riverbed, such as hydrotechnical construction (create of water stages) or transformation of the river banks (concreting of the river banks). The aim of the research was to determine the impact of bridges on the process of water turbidity in the longitudinal profile of large lowland rivers. The research area was the lower reach of Vistula - bridge profiles: Torun, Bydgoszcz, Kiezmark (Poland) and bridge profile on Sukhona - a tributary of the Northern Dvina River near the city of Veliky Ustyug (Russia - Arkhangelsk Oblast). The research conducted in the years 2013-2017 included the measurements of water turbidity in the cross-sections of the above-mentioned rivers. The determinations of water turbidity were carried out using traditional (granulometry analysis) and nephelometric methods (devices: LISST-25X and turbidimeter). The impact of bridges on the variability of water turbidity was determined. The obtained results were related to the variability of depth conditions (bathymetric measurements) and hydrodynamics in the cross-section profile of the channel.
\end{abstract}

Keywords: water turbidity, bridge, lower Vistula River, Sukhona River, suspended sediment continuum, contraction scour

\section{INTRODUCTION}

Ever since the historical times, every human activity has caused interference in the state and functioning of the natural environment. The anthropogenic pressure is particularly reflected in the case of the aquatic environment, which is a very dynamic component, sensitive to changes in various scales.

Human activity, manifested in the aspect of the broadly understood climate change (including increase in average air temperature, melting of glaciers) is reflected in the global balance of sediment supply to the world ocean [Syvitski, Milliman, 2007]. In the historical times the changes of land use caused an increase in the supply of sediments to the rivers of the world [Saito et al., 2001]. However, nowadays there is a decrease in the supply of sediment in the world due to its capture in artificial reservoirs [Walling, Fang, 2003]. The balance of the river sediment supply shows the spatial and temporal changes taking place in the river systems, which are also reflected in the morphological transformations of the river channels [Turowski et al., 2010].

The presence of a pier or several piers of a bridge in the active river channel directly affects the changes in hydraulic parameters of the channel in the bridge profile. The values of parameters such as width, depth and flow velocity will vary with the varying volume of discharge [Leopold, Maddock, 1953]. The impact of the pier on the hydraulic parameters of discharge was also noted in the section of the river above and below the structure. Above, the depth of the channel will increase as a result of damming up of the water, and 
lowering the water level below the bridge profile [Wang et al., 2016; Testa et al., 2007]. Especially in the case of high water discharges, limiting the capacity of the channel in the bridge profile may be the cause of material damage [Rigby et al., 2002; Takara, 2014], including river bottom scour at the site of hydrotechnical constructions [Habel et al., 2017]. In their work, Leopold and Maddock [1953] emphasize the increased impact of narrowing the bridge profile on the increase in depth and water velocity indicators while maintaining a constant width of the river channel.

As mentioned above, the specific hydraulic conditions prevailing above and below the bridge profile may result in the formation of local erosion zones in the form of scoure holes or pools, the uncontrolled expansion of which may contribute to the bridge collapse [Richardson, Davis 2001]. Scour is defined as the removal of river sediment from the river channel and river banks as a result of the erosive action of flowing waters [Hamill, 1999]. Depending on the scale of impact, it is characterized as: general scour, contraction scour and local scour [Prendergast, Gavin, 2014]. The general scour covers the degradation processes (erosion) of the river channel as a result of natural seasonality of water stages or availability of sediments in the river bed in the longitudinal profile of the river (course: upper - middle lower) [Forde et al., 1999]. The contraction scour is a result of the reduction in the cross-sectional area of the channel due to construction e.g. bridge piers [Briaud et al., 1999]. The local scour occurs around the bridge piers in mikroscale [Hamill, 1999]. All these processes have an impact on the dynamics of suspended sediments transport, both in the transversal (microscale) profile and the longitudinal profile of the river (macroscale).

The process of erosion of channel sediments around the piers was described by Melville [2008] using a multiparameter function, taking into account the characteristics of: (a) discharge, (b) bed sediment and (c) bridge geometry. The hydrological parameter was described using two components: discharge - reflection of the force acting on the pier, and water stage - time of contact between the structure and water. Additionally, the roughness of bottom sediments around the pier determines the possibility of erosion (redeposition) of sediment. This factor depends on the location of the river in the morphodynamic zone, which determines the type of riverbed material around the structure. In the case of a relatively homogeneous alluvial material of large lowland rivers, there is a different intensity of erosion, transport and deposition processes than in the case of mountainous or upland rivers. The shape of the pier and its dimensions are also important in the case of dynamics of erosion and accumulation of sediments.

In addition to the intensified supply of sediments from the erosion of the river channel in the bridge profile, it is possible to supply sediments from the rainwater drainage system to the river channel directly from the road of the bridge and access roads [Cornish, 2001]. The material is supplied primarily in the flushing process from the road to the receiver (river), reflecting an elevated concentration of suspended material (SSC) and increased turbidity of waters, thus affecting the aquatic biota [Bouska, Paukert, 2010].

The main objective of the research was to determine the impact of bridges on the spatial diversity of SSC in water on the example of large lowland rivers. The research concerned microscale (within the bridge) and macroscale (in the longitudinal profile of the river).

The most important studies on erosion around the bridge piers included: Gregory and Brookes [1983], Breusers and Raudkivi [1991], Austroads [1994], Melville [2008], Amini et al. [2012] and Khosronejad et al. [2012]. The research of Roy and Sahu [2017] dealt with the influence of bridges on the longitudinal continuity of the channel morphology of Kunur River Basin (India). Escauriaza and Sotiropoulos [2011] conducted modeling of the dynamics of scour around the piers taking into account the transport of the bedload. The most important works on the dynamics of sediments transport include: Van Rijn [1984], Kondolf [1997], Vörösmarty et al. [2003], Shotbolt et al. [2005], Hu et al. [2009]. For the study on Vistula and Sukhona River, the following works can be enumerated: Babiński [2002, 2005], Chalov et al. [2015], Habel et al. [2017] and Szatten et al. [2018].

\section{STUDY AREA}

Large lowland rivers are characterized by the presence of alluvial sediments with considerable thickness, which are redeposited under favorable conditions of discharge velocity [Du Boys, 1879]. The rivers with alluvial bottom are characterized by significantly high mobility of the riverbottom and dynamics of transported sediments, including 
the suspended material. As part of this work, the data for three research sites located on two rivers were analyzed. Three sites are located on the Vistula River in the lower and estuary part, while the fourth is found on the Sukhona River, a tributary of the Northern Dvina River (Fig. 1).

In terms of the physico-geographical regionalization, the first two positions are within the region of North European Plain and subregion: the South-Baltic Coast and South-Baltic Lake District. The third position is located in the region of the North-Russian Taiga Lowland - a subregion of Northern Taiga [Kondracki, 2002]. The studied large lowland rivers are characterized by varying degrees of transformation of their catchment area, which has a direct impact on the dynamics of suspended sediment transport. The Vistula River is the largest river of Poland, 1047 $\mathrm{km}$ long [Rocznik, 2017] and the tenth longest river of Europe. The discussed section is part of the lower Vistula, which is under the influence of a single artificial reservoir Wloclawek (commissioned in 1970s, dam located in $675 \mathrm{~km}$, capacity 55 million $\mathrm{m}^{3}$ ). The Sukhona River is located in the northern European part of the Russian Federation. It has a length of $558 \mathrm{~km}$ and the basin minimally transformed by human.

The amount and size of pillars located in the studied river channels is diversified. For example, the bridge in Torun fitted with one pier in the form of a central island (Table 1). The pier limits a free water flow by reducing the active width of the riverbed by $12 \%$. Other objects, although characterized by a larger number of pillars, are of smaller size. The detailed characteristics of the objects were presented in Table 1.

\section{METHODS}

The spatial differentiation of suspended material concentration in water, in addition to the variability of hydraulic parameters, can reveal the human interference in the functioning of the river system. Due to the way of transport, river sediments can be divided into three types: dissolved load, suspended load and bed-material load [Knighton, 1998]. The research was focused on suspended sediments transport, where the particles are transported without contact with the bottom of the river, but some of the transported material may fall off due to a reduction in the discharge of water in the river [Van Rijn, 1984].

Four single measurement series were carried out in 2013-2017. The measurements of water turbidity were carried out each time in two crosssections, one above and one below the bridge crossing, at a distance of one channel width from the building axis. Three measuring stations on the Vistula river were located at bridges in

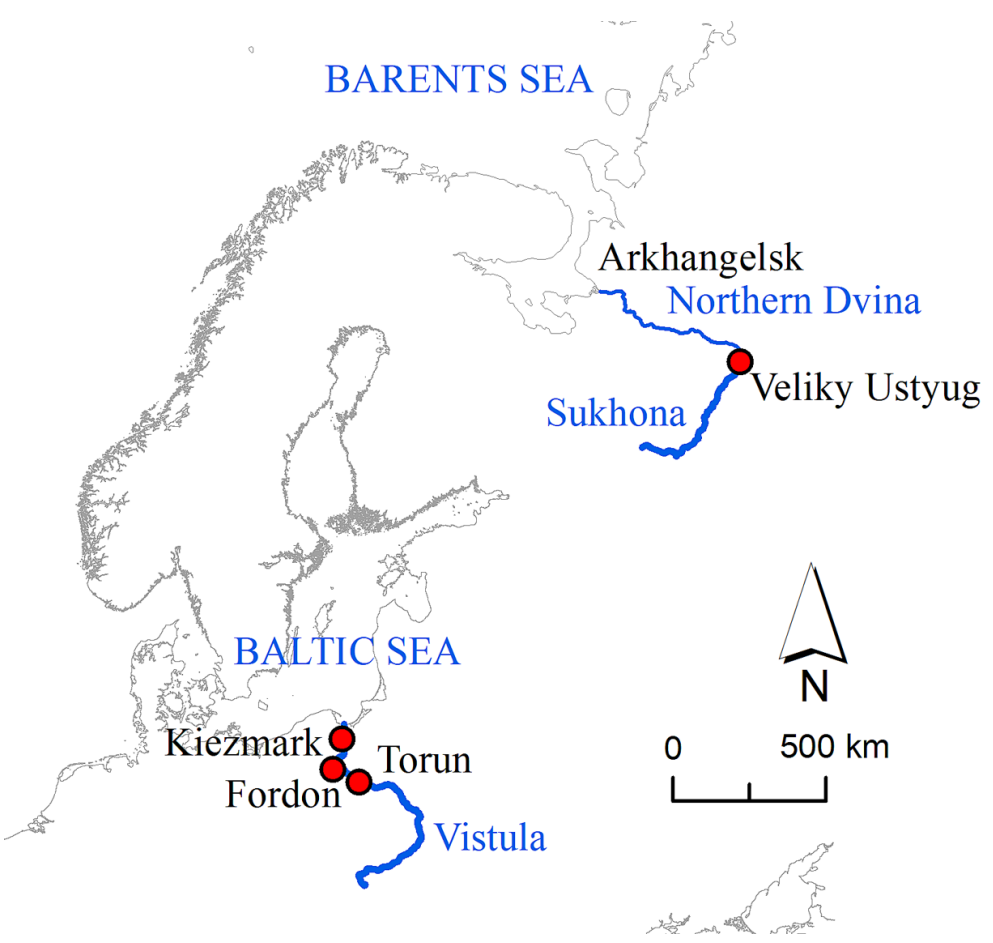

Fig. 1. Location of the research aera [Map of background: HydroSHEDS, 2008]. 
Table 1. Characteristics of bridges on Vistula and Sukhona River

\begin{tabular}{|l|c|c|c|c|}
\hline \multicolumn{1}{|c|}{ Bridges } & Toruń & Fordon & Kiezmark & Veliky Ustyug \\
\hline \multicolumn{1}{|c|}{ River } & \multicolumn{3}{|c|}{ Vistula } & Sukhona \\
\hline Channel width [m] & 410 & 380 & 290 & 385 \\
\hline Number of piers & 1 & 3 & 2 & 4 \\
\hline Width / length of pier [m] & $50 / 130$ & $12 / 25$ & $8 / 12$ & $5 / 12$ \\
\hline Reduction of the active channel width [\%] & 12.0 & 9.5 & 5.5 & 5.2 \\
\hline
\end{tabular}

Torun (km 731.5), in Fordon - Bydgoszcz (km 775.2) and Kiezmark (km 930.0). The fourth station was found in the city of Veliky Ustyug, Sukhona River (1 km long from the estuary to the Northern Dvina River). In addition to sampling conducted using a self-constructed bathometer [Habel et al., 2019] and classical markings of the total suspension (in $\mathrm{mg} \mathrm{l}^{-1}$ ) [Wren et al., 2000] an in-situ research was conducted with the nephelometric (in FNU - Formazin Nephelometric Unit) and optical method. The water turbidity markings were carried out using the HACH 2100QIS turbidimeter [Felix et al., 2016]. By means of LISST 25X optical sensor the grain composition (in $\mu \mathrm{m}$ ) and suspended sediment concentration (in $\mathrm{ml} / \mathrm{l}^{-1}$ ) were determined. The advantage of the LISST sensor (Laser In Situ Scattering Transmissometer) is that the characteristics of suspended material are recorded in real time [Agrawal, Pottsmith, 2000]. The particle size distribution (PSD) of silt in two different sizes (1.25-63 and 63-250 $\mu \mathrm{m})$, volumetric distribution of suspended load and transmission of water was determined. The bathymetric data was collected by a single-beam LOWRANCE HDS-5 Gen 2 echosounder, while simultaneously leveling the water stage with the use of GNSS technology using the RTK GPS receiver. For one test measuring point in Torun, the high-resolution DTM depth model of the Vistula river channel $(1 \times 1 \mathrm{~m})$ was developed in the ArcMAP 10.0 software, which was the basis for modeling the hydrodynamic conditions of the Vistula river using the MIKE 21C software [MIKE 21C, 2011]. The bathymetry (from 16th Dec 2014) was imported into the curvilinear grid $(80 \times 400$ cells). The flow data from the hydrometric station in Torun was used to calibrate the hydrodynamic model.

\section{CONTRACTION AND LOCAL SCOUR}

The local scour may occur in two types: clear-water and live-bed scour. Generally, in the clear-water scour there is no movement of bed materials [Brandimarte et al., 2006; Hosseini, Amini, 2015]. In the waters of the considered rivers, sediments are transported; hence, the intensity of erosion and accumulation processes are significant. The presence of a pier in the riverbed disturbs the already inhomogeneous discharge. Around the obstacle (pier) a series of vortexes was distinguished: surface roller - affecting the upper part of the structure, horseshoe vortex contributing to the erosion processes above the pier and wake vortex - causing accumulation below the obstacle [Baker, 1980; Ettema et al., 2006; Sheppard and Renna, 2010]. Their occurrence contributes to the increase in the dynamics of erosion and accumulation processes, especially depending on the morphological conditions of the river channel.

The depth conditions of the channel determine the course of sediments lifting from the bottom (erosion) and deposition of suspended material. The shape of Vistula River channel near Torun is characterized by asymmetry. The first site on the Vistula River (in Torun) is located on the riverbend, where systematically larger depths occur at the right bank (river bank erosion), while along the left bank there is a pseudo-meander sandbar - a zone of increased sediment accumulation (Fig. 2). The development of large accumulation forms, in particular in the case of large alluvial rivers with sandy bars in the riverbed, plays a significant role in the process of shaping the riverbed morphology. The research of Noormets et al. [2006] showed the impact of the sandbars presence around the piers on the reduction of the erosion process. However, the river bottom scour within the piers may contribute to the intensification of the erosion process, which was found in the studies of Mieszkowski et al. [2017] on the Vistula River near Warsaw.

Modeling of the hydrodynamic conditions of the Vistula River near Torun using the MIKE 21C software enabled to identify areas of the channel sensitive to the occurrence of the erosion / 
accumulation process. Using of curvilinear grid lines following the bank lines of the river, provided a better resolution of the flow near the boundaries [MIKE 21C, 2011]. The application of MIKE $21 \mathrm{C}$ allows predicting bed deformations, pools and sandbars migration near pier with reference to the Vistula River. The increased water velocity in the riverbed can be associated with the possibility of erosion (lifting of sediments) and the areas with increased SSC (Fig. 2A). The water flow around the pillar was also noticed (Fig. 2B), which is conditioned by the depth of the water in the riverbed. Above the pier, a strong turbulence zone was formed, directing the majority of the Vistula waters along the right bank, while behind the pier and along the left bank, a zone characterized by a lack of active water flow was formed. This determines the processes of erosion (around the pier) and deposition in the inactive part of the channel.

The measurements of water turbidity near the bridge in Torun (Vistula River) confirm the above-mentioned regularities (Fig. 3). The values observed above bridge oscillate at a higher level than in the profile below. In addition, the turbidity of water below the pier of the bridge is noticeable, which indicates the impact of the structure on the dynamics of suspended sediments in the microscale.

While analyzing the turbidity distribution in the cross-sectional profile of the studied rivers, there was no significant variation in value (Fig. 4). For the Vistula River, both in Torun and Fordon, the irregularity of value amounted up to 0.950 and fluctuated in the range from 13.1 FNU at the accumulation bank in Fordon (Fig. 4B) to 23.4 FNU in the stream in Torun (Fig. 4A). The water turbidity of Sukhona reaches its values at a higher level (Fig. 4C), due to its location in another morphodynamic zone, conditioning the increased supply of suspended sediment. There was a correlation between the increase in water turbidity in the part of the channel leading the main part of water (stream) and near the erosive bank. Below the exceedances, lower SSC were recorded in most cases, which is related to the dynamics of water.
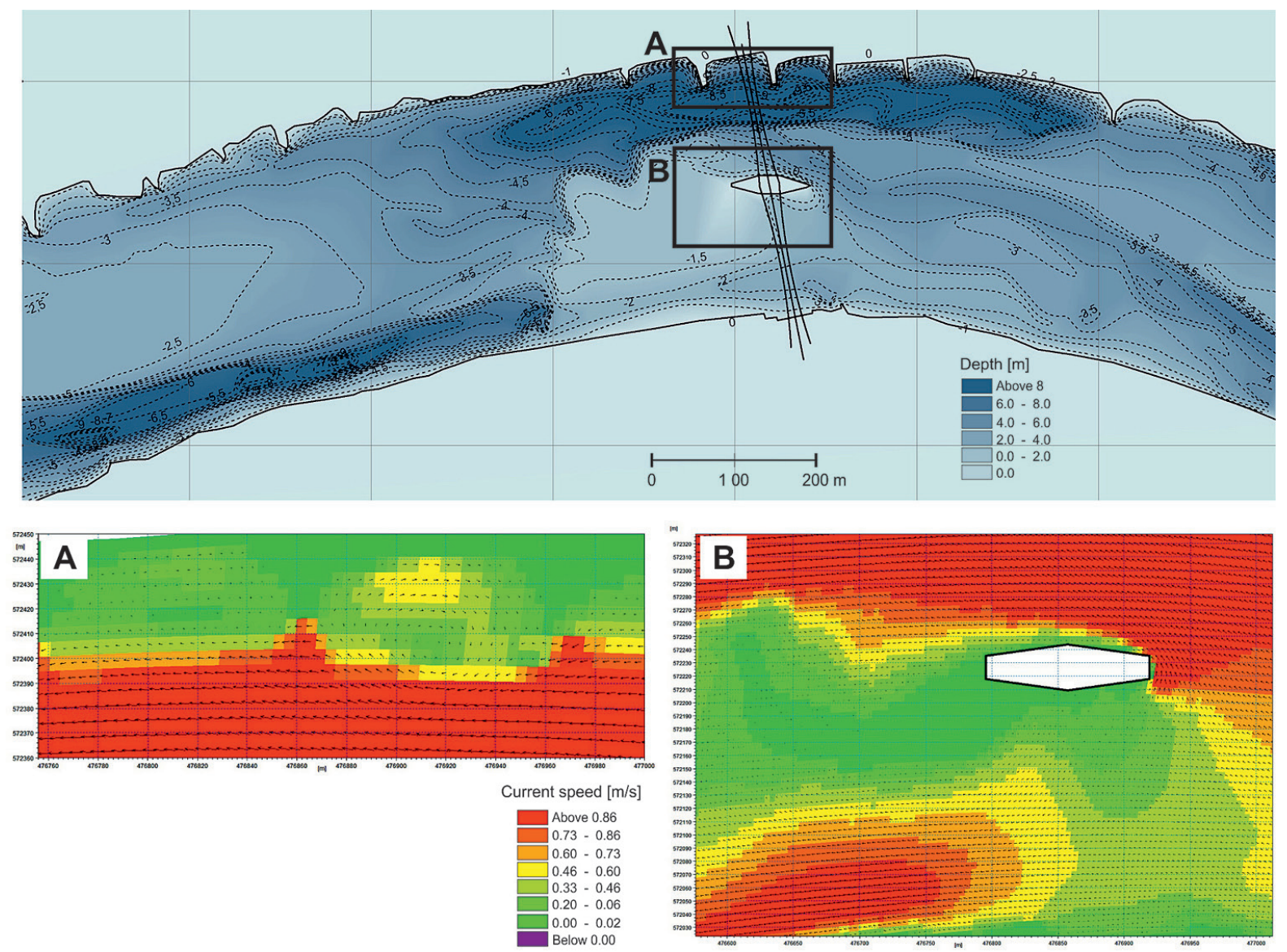

Fig. 2. Reflection of the hydrodynamic conditions $\left(\mathrm{Q} \sim 1000 \mathrm{~m}^{3} \mathrm{~s}^{-1}\right)$ for the Torun station (bathymetric map 16th Dec 2014); distribution of directions and velocity of water flownear: A - right bank; B - pier. 
A

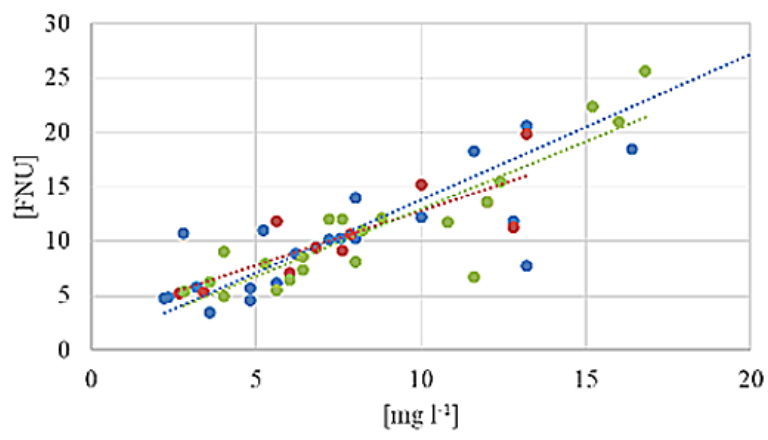

B

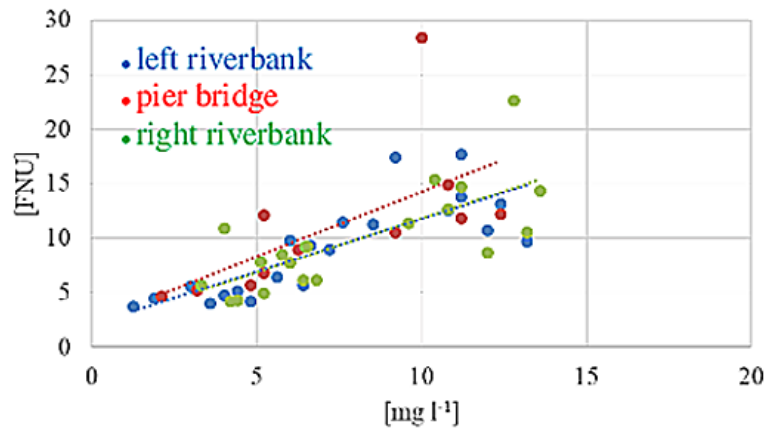

Fig. 3. Relationship between SSC determined by traditional methods (in $\mathrm{mgl}^{-1}$ ) and nephelometric (in FNU) in the profiles above (A) and below (B) of the bridge in Torun in years 2013-2016 with division into the left bank, pier zone and right bank.

A

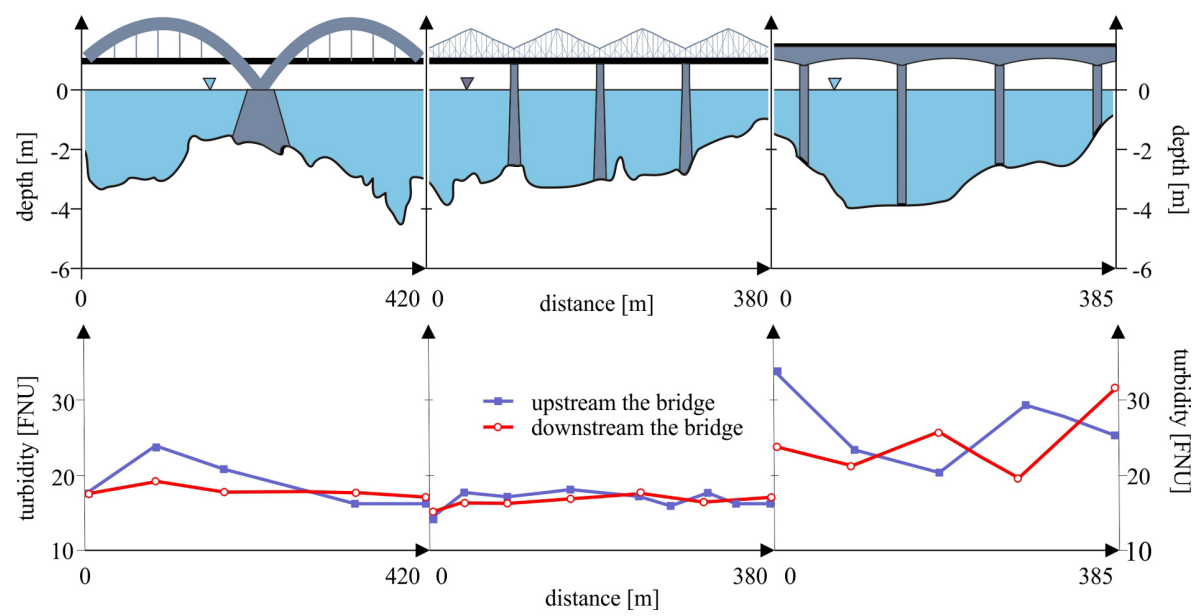

Fig. 4. The course of changes in water turbidity in selected cross-sectional bridge profiles of the Vistula (A - Torun, B - Fordon) and Sukhona (C - Veliky Ustyug) in 2014.

\section{GENERAL SCOUR}

The average annual supply of clastic sediments to the Wloclawek Reservoir was specified at the level of 2.9 million tonnes, of which 0.7 million tonnes are suspended sediments [Babiński, 2005]. The entire bedload material is accumulated in the reservior, whereas the accumulation of the sespended sediments was estimated at about $42 \%$ [Babiński, 2002]. The process of sediments renewal below the water stage, discussed by Kondolf [1997], determines the dynamics of the suspended material, also near the bridges. The research of Zheng et al. [2018] conducted on the Yangtze River indicates that the reduction of the suspended sediment transport contributes to the increase of the riverbed erosion intensity [Babiński and Habel, 2017] and bridge scour.

While analyzing the values of SSC in the longitudinal profile of the Vistula River, a systematic increase in the value along with the growth in catchment area is noticeable (Figure $5 \mathrm{~d}$, e). The values oscillate at a level from about $60 \mathrm{ml} \mathrm{l}^{-1}$ for Torun to about $200 \mathrm{ml} \mathrm{l}^{-1}$ for the station in Kiezmark. This is characteristic for large lowland rivers where an increase in the pressure and supply of sediments is observed, both from the natural and anthropogenic sources. An increase in the size of the grains and its diversification is also observed (Figure $5 \mathrm{f}, \mathrm{g}$ ). For the Torun and Fordon stations, the average PSD of the suspended sedminets and the average grain size above $63 \mu \mathrm{m}$ do not exceed 25 and $85 \mu \mathrm{m}$, respectively. This corresponds to granulometric groups [Polskie Towarzystwo Gleboznawcze, 2008] clay loam and silt loam. For the Vistula estuary station, these indicators increase to 40 and $220 \mu \mathrm{m}$ respectively, classifying the size of the suspension grains according to the groups of silt loam and fine sand. This indicates an increase in the number of sources for 
the supply of sediments. However, compared to the morphological conditions of the river channel and the presence of piers (Figure $5 \mathrm{~b}$ ), the obtained values in the cross-sections do not show a clear impact of bridges on the dynamics of the suspended sediments. They only confirm (as discussed earlier) the influence of the local morphological and hydrological conditions (zones of erosion and accumulation in the riverbed, the velocity of water) on the water turbidity. The studies of Ettema [1980] and Sheppard et al. [2004] indicate the accumulation of riverbed above the obstacles with a relatively large grain size, as opposed to the riverbed area below the obstacle where fine sediment is retained.

\section{CONCLUSION}

Undoubtedly, bridges constitute an obstacle to the free outflow of water in the river channel during low and high discharges both. The investigated bridge structures had the free flow of the water (from 12 to $5.2 \%$ ) limited to different degrees. Thus, they disturb the so-called river continuum, interrupting the continuity of river sediments transport, which was one of the aims in this paper. Each river, as regards ecology, is an open ecosystem in a state of a dynamic equilibrium [Allan, 1998]. According to the river continuum concept (RCC) by Vannote et al. [1980] breaking its continuity undoubtedly influences the changing hydrological conditions in the uppstream and dowstream of teh bridge.

On the basis of the conducted studies on the dynamics of suspended sediments in the area of the lower Vistula and Sukhona, the following conclusions can be drawn:

1. The hydrodynamic conditions, mainly dependent on the discharge (water stage) in the river channel, determine the processes of sediments supply (erosion) to the fluvial system.

2. The hydrotechnical constructions in the form of bridge piers locally influence (in a microscale) the variability of water turbidity along the longitudinal profile of rivers, which confirms the impact on sediment transport continuity.

3. However, their presence in the river channel determines the course of depth and hydrodynamic conditions in the river channel, which in turn has a direct impact on the course of erosion and the sediment deposition processes,

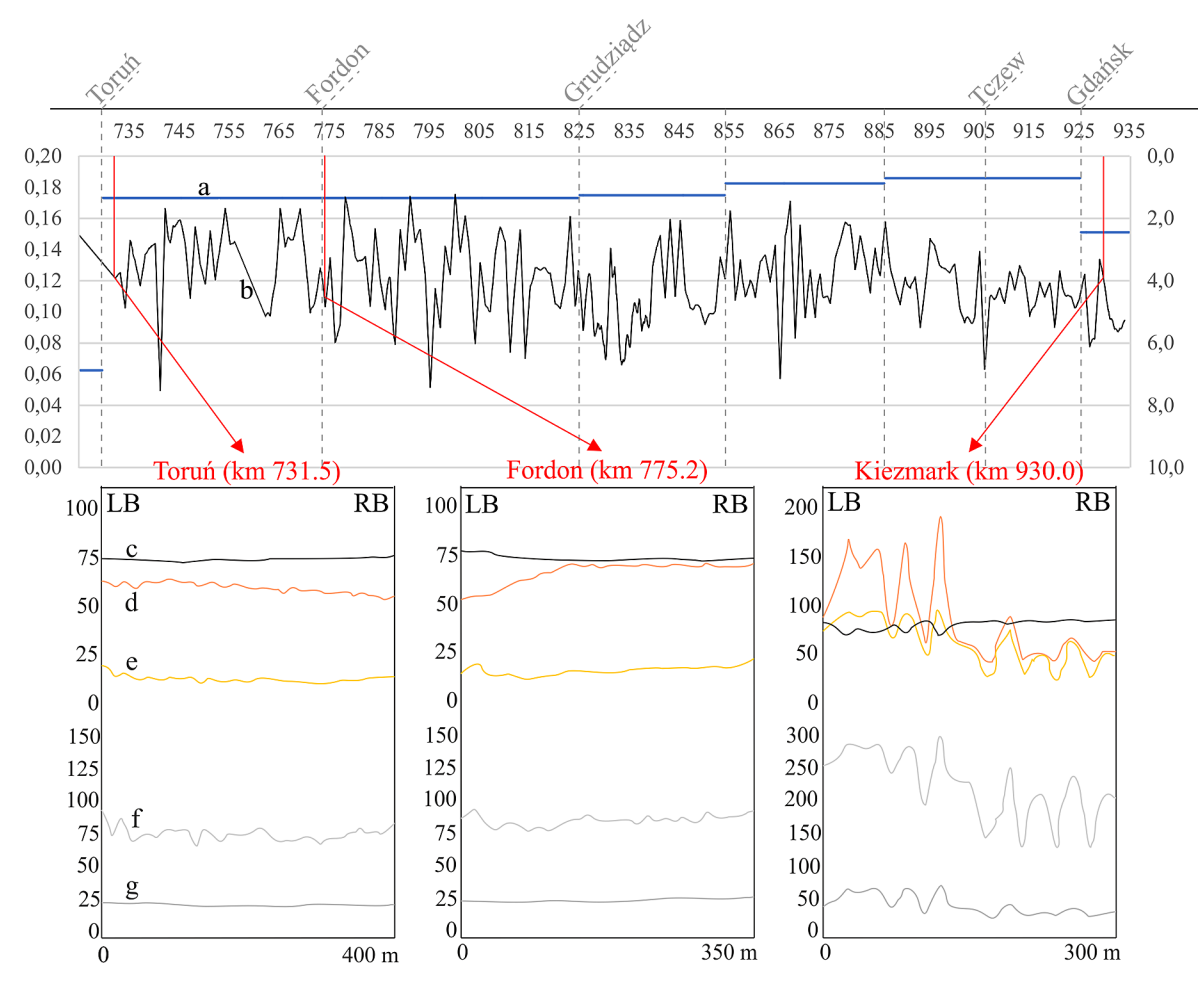

Fig. 5. Characteristics of the suspended load against the background of the morphological conditions of the river channel in the selected cross-sections profiles of the Vistula: a) water surface slope at average flows between the gauging stations, in \%o; b) channel depths of the river thalweg, in m; c) water transmission, in \%; d) SSC, in $\mathrm{ml} \mathrm{l}^{-1}$; e) $\%$ part of grains $>63 \mu \mathrm{m}$ in the total SSC; f) average grain size $>63 \mu \mathrm{m}$; g) the average PSD of the suspended sediments, in $\mu \mathrm{m}$; LB - left bank, RB - right bank. 
including the suspended material. These characteristics directly affect the balance of suspended sediments in the longitudinal profile of the river (in macroscale), showing the indirect impact of the bridges (piers).

4. The existence of pillars in the riverbed reduces the active width of the channel (up to $12 \%$ ), which affects the local damming of water and slows down the water flow above them.

5. A local reduction of water turbidity below objects was observed by an average of $6 \%$ for the Vistula River and by 9\% for Sukhona River.

6. Two methods of turbidity measurement were used, the classic (weight method, in $\mathrm{mgl}^{-1}$ ) and the optical one (real-time measurement, in FNU), which gave similar results in terms of the quality of the phenomenon assessing.

7. The sediment analysis in terms of PSD in all tested profiles did not show a clear impact of the pillars on the differences in suspended material grain size. The PSD analyses only confirm the influence of local morphological conditions on the diversity of water turbidity in the transverse profile of the river.

\section{Acknowledgements}

The research was funded by Polish Ministry of Science (Maintenance of the Research Potential of the Department of Physical Edu., Health and Tourism at Kazimierz Wielki University; no. $\mathrm{BS} / 2016 / \mathrm{N} 2$ ).

\section{REFERENCES}

1. Agrawal Y.C., Pottsmith H.C. 2000. Instruments for particle size and settling velocity observations in sediment transport. Mar. Geol., 168, 89-114.

2. Allan J.D. 1998 Ekologia wód płynących. PWN, Warszawa.

3. Amini A., Melville B.W., Ali T.M., Ghazli A.H. 2012. Clearwater local scour around pile groups in shallow-water flow. Journal of Hydraulic Engineering, ASCE, 138(2), 177-185.

4. Austroads: Waterway design - A guide to the hydraulic design of bridges, culverts and floodways. 1994. Austroads, Sydney.

5. Babiński Z. 2002. Wpływ zapór na procesy korytowe rzek aluwialnych ze szczególnym uwzględnieniem Zbiornika Włocławskiego. Wyd. Akademii Bydgoskiej im. Kazimierza Wielkiego, Bydgoszcz.

6. Babiński Z. 2005. The relationship between suspended and bed load transport in river channels.
Proc. International Symposium held at the 7th Scientific Assembly of the International Association of Hydrological Sciences, 182-188.

7. Babiński Z., Habel M. 2017. Impact of a single dam on sediment transport continuity in large lowland rivers. [in:] Wieprecht S., Haun S., Weber K., Noack M., Terheiden K. (ed.) River Sedimentation. Taylor \& Francis CRP Press.

8. Baker C. 1980. The turbulent horseshoe vortex. J Wind Eng. Indus. Aerodyn, 6, 9-23.

9. Bouska W.W., Paukert C.P. 2010. Road crossing designs and their impact of fish assemblages of Great Plains streams. Transactions of the American Fisheries Society, 139, 214-222.

10. Brandimarte L., Montanari A., Briaud J.L. D’Odorico P. 2006. Stochastic flow analysis for predicting river scour of cohesive soils. Journal of Hydraulic Engineering, 132(5), 493e500.

11. Breusers H.N.C., Raudkivi A.J., 1991. Scouring. Hydraulic Structures Design Manual, 2, I.A.H.R., Balkema.

12. Briaud J.L., Ting F., Chen H.C., Gudavalli R., Perugu S., Wei G. 1999. SRICOS: prediction of scour rate in cohesive soils at bridge piers. Journal of Geotechnical and Geoenvironmental Engineering, 125(4) $237 \mathrm{e} 46$.

13. Chalov S., Habel M., Zawadskyi A., Golowlev P., Szatten D., Letnikova W., 2015. Morphodynamic consequences of anthropogenic impacts on the rivers of Northern Europe (Vistula and Northern Dvina). [in:] Erosion and fluvial processes. Chalov R. (eds.), Geographical Faculty of Moscow State University.

14. Cornish P.M. 2001. The effects of roading, harvesting, and forest regeneration on streamwater turbidity levels in a moist eucalypt forest. Forest Ecology and Management, 152, 293-312.

15. Du Boys M. P. 1879. Etudes du regime et l'action exercé par les eaux sur un lit a fond de gravier indéfiniment affouiable. Annales des Fonts et Chaussées, 5, 141-195.

16. Escauriaza C., Sotiropoulos F. 2011. Initial stages of erosion and bed-form development in turbulent flow past a bridge pier. J Geophys Res, 116:F03007.

17. Ettema R., 1980. Scour at bridge piers. Report No. 216, School of Engineering, The University of Auckland, Auckland.

18. Ettema R., Kirkil G., Muste M., 2006. Similitude of large-scale turbulence in experiments on local scour at cylinders. Journal of Hydraulic Engineering, A.S.C.E., 132(1), 33-40.

19. Felix D., Albayrak I., Abgottspon A., Boes R. M. 2016. Real-time measurements of suspended sediment concentration and particle size using five techniques. Proc. IOP: Earth and Environmental Science, 1057-1066. 
20. Forde M.C., McCann D.M., Clark M.R., Broughton K.J., Fenning P.J., Brown A., 1999. Radar measurement of bridge scour. NDT\&E International, 32(8), 481e92.

21. Gregory K. J., Brookes A., 1983. Hydrogeomorphology downstream from bridge. Applied Geography, 3(2), 145-159.

22. Habel M., Babiński Z. Szatten D. 2017. A comparison of research approaches in estimation of volume changes of a bed load transport along a river course on the example of a large lowland river. Proc. of the International Conference of Computational Methods in Sciences and Engineering, 170009(1-4).

23. Habel M., Obodovskiy O., Onyshuk O., Babiński Z., Szatten D., 2019. Device for sampling sediment from water bodies, UA Patent 131903, filed June 25, 2018, and issued February 11, 2019, https://patents. google.com/patent/UA131903U

24. Hamill L. 1999. Bridge hydraulics. E\& FN Spon, London.

25. Hosseini R., Amini A. 2015. Scour Depth Estimation Methods around Pile Groups. KSCE Journal of Civil Engineering, 19(7), 2144-2156.

26. Hu B., Yang Z., Wang H., Sun X., Bi N., Li G. 2009. Sedimentation in the Three Gorges Dam and the future trend of Changjiang (Yangtze River) sediment flux to the sea. Hydrol. Earth Syst. Sci., 13, 2253-2264.

27. HydroSHEDS. 2008. USGS, http://www.worldwildlife.org/hydrosheds.

28. Khosronejad A., Kang S., Sotiropoulos F. 2012. Experimental and computational investigation of local scour around bridge piers. Advances in Water Resources, 37, 73-85.

29. Knighton D. 1998. Fluvial forms and processes. A new perspective. Co-published John Wiley and Sons Inc., New York.

30. Kondolf G. 1997. Hungry water: Effects of Dams and Gravel Mining on River Channels. Environ. Manage, 21(4), 533-551.

31. Kondracki J. 2002. Geografia regionalna Polski. Wyd. Nauk. PWN, Warszawa.

32. Leopold L.B., Maddock T. 1953. The Hydraulic Geometry of Stream Channels and Some Physiographic Implications. United States Goverment Printing Office.

33. Melville B. 2008. The physics of local scour at bridge piers. Fourth International Conference on Scour and Erosion.

34. Mieszkowski R., Wójcik E., Żmudzin D., Szwarc A., Sosnowska A., Popielski P. 2017. Zastosowanie metody georadarowej do identyfikacji stref erozji dna rzecznego na przykładzie wybranego odcinka doliny Wisły w Warszawie. Przegląd Geologiczny, 65(10/2), 785-789.
35. MIKE 21C. 2011. Curvilinear Model for River Morphology, User Guide, DHI Water \& Environment.

36. Noormets R., Ernstsen V. B., Bartholomä A., Flemming B. W., Hebbeln D. 2006. Implications of bedform dimensions for the prediction of local scour in tidal inlets: a case study from the southern North Sea. Geo-Marine Letters, 26(3), 165-176.

37. Polskie Towarzystwo Gleboznawcze. 2008. Klasyfikacja uziarnienia gleb, PTG, http://www.ptg.sggw. $\mathrm{pl} /$ uziarnienie.html

38. Prendergast L.J., Gavin K. 2014. A review of bridge scour monitoring techniques. Journal of Rock Mechanics and Geotechnical Engineering, 6, 138e149.

39. Richardson E.V., Davis S.R. 2001. Evaluating scour at Bridges. 4th Edition, Federal Highway Administration Hydraulic Engineering Circular No. 18, FHWA NHI 01-001.

40. Rigby E.H., Boyd M.J., Roso S., Silveri P., Davis A. 2002. Causes and effects of culvert blockage during large storms. [in:] Strecker E.W., Huber W.C. (ed.) Proceedings of 9th International Conference on Urban Drainage (9ICUD). Reston, VA: American Society of Civil Engineers, 1-16.

41. Rocznik statystyczny Rzeczpospolitej Polskiej. 2017. GUS, Warszawa.

42. Roy S., Sahu A.S. 2017. Road-stream crossing an in-stream intervention to alter channel morphology of headwater streams: case study. Intl. J. River Basin Management, 16(1) DOI: 10.1080/15715124.2017.1365721.

43. Saito Y., Yang Z.S., Hori K. 2001. The Huanghe (Yellow River) and Changjiang (Yangtze River) deltas: a review on their characteristics, evolution and sediment discharge during the Holocene. Geomorphology, 41, 219-231.

44. Sheppard D.M., Odeh M., Glasser T. 2004. Large scale clear-water local pier scour experiments. Journal of Hydraulic Engineering, 130(10), 957-963.

45. Sheppard D.M., Renna R. 2010. Bridge scour manual. 605 Suwannee Street. Tallahassee, FL 32399-0450.

46. Shotbolt L.A., Thomas A.D., Hutchinson S.M. 2005. The use of reservoir sediments as environmental archives of catchment inputs and atmospheric pollution. Progress in Physical Geography, 29(3), 337-361.

47. Syvitski J.P.M., Milliman J.D. 2007. Geology, geography, and humans battle for dominance over the delivery of fluvial sediment to the coastal ocean. J. Geol, 115, 1-19.

48. Szatten D., Babiński Z., Habel M. 2018. Reducing of Water Turbidity by Hydrotechnical Structures on the Example of the Wloclawek Reservoir. Journal of Ecological Engineering, 19(3) 197-205. 
49. Takara K. 2014. Urban flood risks. J. Flood Risk Manage, 7, 289-290.

50. Testa G., Zuccalà D., Alcrudo F., Mulet J., SoaresFrazão S. 2007. Flash flood flow experiment in a simplified urban district. J. Hydraulic Res., 45(supp1), 37-44.

51. Turowski J.M., Rickenmann D., Dadson S.J. 2010. The partitioning of the total sediment load of a river into suspended load and bedload: A review of empirical data. Sedimentology, 57, 1126-1146.

52. Van Rijn L. 1984. Sediment Transport. Part III: Bed forms and alluvial roughness. Journal of Hydraulic Engineering, 110(12), 1733-1754.

53. Vannote, R.L., G.W. Minshall, K.W. Cummins, J.R. Sedell, and C.E. Cushing. 1980. The river continuum concept. Canadian Journal of Fisheries and Aquatic Sciences 37: 130-137.

54. Vörösmarty C.J., Meybeck M., Fekete B., Sharma K., Green P., Syvitski J.P.M. 2003. Anthropogenic sediment retention: major global impact from registered river impoundments. Global and Planetary Change, 39(1-2), 169-190.

55. Walling D.E., Fang D. 2003. Recent trends in the suspended sediment loads of the world's rivers. Global Planet. Change, 39, 111-126.

56. Wang H., Tang H., Xu X., Xiao J., Liang D. 2016. Backwater effect of multiple bridges along Huaihe River, China. Proceedings of the ICE Water Management.

57. Wren D., Barkdoll B., Kuhnle R., Derrow R. 2000. Field Techniques for Suspended-Sediment Measurement. Journal of Hydraul. Eng., 126(2), 97-104.

58. Zheng S., Xu Y., Cheng H., Wang B. 2018. Assessment of bridge scour in the lower, middle, and upper Yangtze River estuary with riverbed sonar profiling techniques, Environ Monit Assess. 190: 15, https://doi.org/10.1007/s10661-017-6393-5. 